\title{
Símbolos religiosos em espaços públicos: para pensar os conceitos de laicidade e secularização
}

\author{
Religious symbols in public spaces: \\ thinking about the concepts of secularism and secularization
}

Clemildo Anacleto Silva

RESUMO

Esse texto tem por objetivo demonstrar o resultado de uma pesquisa acerca da presença de símbolos religiosos em espaços públicos na cidade de Porto Alegre bem como refletir sobre o conceito de laicidade e o significado do símbolo religioso no espaço público aberto, como praças, ruas, calçadas, praias, parques etc. Discutiremos a respeito do significado do símbolo religioso e se sua presença implica o comprometimento à implementação de uma sociedade laica. Os resultados da pesquisa demonstraram que os entrevistados aceitaram com naturalidade a presença dos símbolos; entenderam essa presença como valorização da diversidade e respeito aos mais variados grupos religiosos; enxergaram o poder público como promotor da democracia uma vez que não privilegiou apenas uma tradição.

PALAVRAS-CHAVE: Símbolo religioso; Laicidade; Tolerância.

ABSTRACT

This paper aims to demonstrate the results of a survey about the presence of religious symbols in public spaces in Porto Alegre, as well as reflects on the concept of secularism and the meaning of the religious symbols in public open space such as squares, streets, sidewalks, beaches, parks etc. We will discuss the meaning of the religious symbol and if its presence implies the commitment to implement a secular society. The survey results showed that the respondents accepted naturally the presence of the symbols; they understood this presence as valuing diversity and respect for various religious groups; they see the government as a promoter of democracy as it did not favor only one tradition.

KEYWORDS: Religious symbol; Secularism; Tolerance.

\footnotetext{
' Recebido em 20/11/2016. Aprovado em 20/01/2016.

2 Doutor em Ciência da Religião. Professor do Centro Universitário Metodista - IPA, de Porto Alegre. E-mail: clemildo.silva@metodistadosul.edu.br.
} 


\section{l. Introdução}

Neste texto, pretendemos analisar a compatibilidade entre laicidade e a presença de símbolos religiosos em espaços públicos, bem como estudar o conceito de laicidade e suas implicações para a sociedade atual, a partir de uma pesquisa realizada pelo Núcleo de Pesquisa sobre Intolerância Religiosa e Direitos Humanos ${ }^{3}$. O estudo teve como foco procurar entender de que forma a presença de símbolos religiosos em espaços públicos influencia no conceito de laicidade e se as respostas dos entrevistados revelam um conceito que compromete ou não a implementação de um Estado laico.

Assim sendo, esta pesquisa estabeleceu a seguinte metodologia: entrevistou quarenta pessoas que se encontravam próximas a quatro símbolos religiosos da cidade de Porto Alegre, capital do Rio Grande do Sul, com o objetivo de saber qual era a opinião delas acerca da presença daqueles símbolos no espaço público e se elas eram favoráveis ou desfavoráveis à retirada do símbolo daquele espaço. Assim, os participantes foram abordados próximos aos símbolos para que pudessem enxergá-los. O símbolo precisava estar visível para o entrevistado. Os entrevistados responderam a duas questões que foram registradas com auxílio de um gravador portátil: 1. O que você acha da presença de um símbolo religioso num espaço público? 2. Você é favorável ou contrário à retirada do símbolo religioso do espaço público?

Os símbolos escolhidos foram os seguintes: imagem do Buda, que está colocada em um grande e popular parque da cidade, conhecido como Parque da Redenção. O segundo diz respeito à imagem de Oxum, presente na orla do lago Guaíba, em Ipanema, bairro de classe média da cidade de Porto Alegre. O terceiro símbolo refere-se ao Candelabro, localizado na pequena Praça Silvio Ughini, próxima ao viaduto da Av. Silva Só. Essa praça faz parte do Bairro Bomfim, conhecido como o bairro judeu de Porto Alegre. O último símbolo observado foi o monumento à Bíblia, erguido em uma praça na Av. Borges de Medeiros, próxima ao Fórum Central.

\footnotetext{
${ }^{3}$ O Núcleo de Pesquisa está vinculado ao Programa de Pós-graduação do Centro Universitário Metodista IPA de Porto Alegre. A pesquisa foi concluída em junho de 2016.
}

Numen: revista de estudos e pesquisa da religião, Juiz de Fora, v.19 n.2, 2016, p. 154-173. 
Neste texto, apresentaremos os resultados dessa pesquisa, confrontando com o debate sobre laicidade e intolerância religiosa a partir da discussão que envolve a presença de símbolos religiosos no espaço público. Mais especificamente, buscaremos discutir se a presença de símbolos religiosos nos espaços públicos compromete o conceito de Estado laico. Com o objetivo de melhor analisar o assunto, entendemos que se faz necessário, primeiramente, discutirmos a respeito do significado do símbolo religioso e do conceito de laicidade e, no segundo momento, passamos a apresentar os resultados da pesquisa.

\section{Símbolo religioso e espaço público}

Os símbolos escolhidos para essa pesquisa são imagens de fácil visibilidade, constituindo-se de grandes construções presentes em espaços de ampla circulação. Contudo, o único símbolo que possivelmente esteja menos visível seja o Candelabro, devido ao fato de estar encoberto por algumas árvores, dificultando, assim, sua observação.

Em geral, todos os símbolos encontram-se bem cuidados. Não se verificaram notáveis ações de vandalismo contra nenhum deles. $\bigcirc$ monumento à Bíblia, localizado em uma grande praça central e bem frequentada pelos moradores, mesmo apresentando algumas pichações, está preservado.

A localização dos símbolos pode também estar relacionada a outra questão simbólica. No caso da Bíblia, muitas vezes, aparece em repartições ou em prédios ligados ao judiciário. Esse monumento de Porto Alegre está colocado em uma praça que fica em frente ao Fórum Central. Como afirma Giumbelli: "Pois se a presença de Bíblias em tribunais não ganha registros, ela se torna comum nos plenários e parlamentos" $(2014$, p. 162). É possível que os proponentes desse símbolo quisessem mostrar que a Bíblia é a Lei Maior, ou ainda que a justiça deva tomar como base os preceitos bíblicos. $\bigcirc$ protestantismo brasileiro mais conservador sempre deixou clara sua intenção de construir um país que se pautasse pelos princípios bíblicos e, mais especificamente, pelos princípios protestantes.

Gondim (2015) tem essa mesma percepção quando afirma que: 
Eu gostaria de ver o Brasil permeado com a elegância, solidariedade, inclusão e compaixão do Evangelho. Mas a mensagem subliminar dos outdoors, para quem conhece a cultura do movimento evangélico, é outra. Os evangélicos sonham com o dia em que cidade, estado e país se convertam em massa, e a terra dos tupiniquins tenha a cara de suas denominações.

Um dos argumentos usados quando se discute a presença de símbolos religiosos nos espaços públicos é o de que eles constrangem aqueles que não comungam da mesma experiência religiosa ou aqueles que não expressam nenhuma religião. Segundo essa visão, o símbolo religioso presente num espaço público transmite uma mensagem de que a gestão pública fez opção por uma experiência religiosa, excluindo aquelas crenças que são menos dignas de reconhecimentos. Simbolicamente também demonstra que a gestão pública continua estabelecendo uma relação de privilégio na qual algumas experiências religiosas são excluídas e apenas uma é beneficiada. (GIUMBELLI, 2014).

Embora essa não fosse a principal preocupação da nossa pesquisa, a metodologia adotada nos permitiu saber se os entrevistados se sentiam constrangidos ou não com a presença do símbolo religioso.

A maioria das reflexões sobre o assunto se limita a debater sobre os símbolos religiosos presentes nos espaços públicos fechados (escolas, universidades, hospitais, Câmaras, Fóruns etc.). Nossa preocupação se voltou para a presença do símbolo no espaço público aberto, ou seja, o espaço físico relacionado a praças, calçadas, orla dos rios, praias e outros.

Não raro, surge, na sociedade, uma polêmica envolvendo símbolo religioso. A última disse respeito à encenação durante a parada LGBT, no dia 07 junho de 2015 em São Paulo, em que uma travesti desfilou simulando uma crucificação. Essa imagem foi objeto de debate nas redes sociais por parte de alguns grupos cristãos.

Em princípio, entendemos que todos os símbolos religiosos merecem respeito visto que carregam consigo uma aura do sagrado. Simbolizam a experiência do mistério e, muitas vezes, simbolizam a própria presença da divindade.

É necessário também reconhecer o direito de livre manifestação, sendo importante, no entanto, observar o limite entre a crítica e o desrespeito ou a intolerância. A Declaração Sobre a Eliminação de Todas as Formas de Intolerância e Discriminação Fundadas na Religião ou nas Convicções, em seu artigo segundo, define intolerância da seguinte forma: "entende-se por intolerância e discriminação baseadas na religião ou nas 
convicções toda a distinção, exclusão, restrição ou preferência fundada na religião ou nas convicções e cujo fim ou efeito seja a abolição ou o fim do reconhecimento, o gozo e o exercício em igualdade dos direitos humanos e das liberdades fundamentais."

A sociedade brasileira já se acostumou com a presença de símbolos religiosos nos espaços públicos. Em geral, a sociedade não estranha essa presença, pelo contrário, convive de forma pacífica enxergando os símbolos com naturalidade.

No entanto, cabe aqui uma observação: essa passividade e naturalidade dizem respeito muito mais aos símbolos relacionados ao cristianismo. Quando se trata de símbolos de outros grupos, principalmente daqueles que representam a religiosidade de Matriz Africana, esse convívio não é tão pacífico. Diante da polêmica que, muitas vezes, o símbolo pode ou tem causado, cabe a seguinte pergunta: afinal, o que é um símbolo religioso? É o que procuraremos mostrar no item seguinte.

\section{O que um símbolo religioso representa?}

que são, portanto, símbolos religiosos? Estes podem ser descritos como objetos, imagens, pessoas ou tradições que um grupo religioso a eles esteja vinculado, reconhecendo-os como portador ou representante de uma esfera sagrada. $\bigcirc$ símbolo religioso é assim reconhecido, pois é parte integrante da tradição religiosa e de seus rituais, se apresentando, muitas vezes, como objeto de veneração.

Nesse sentido, o símbolo religioso é uma manifestação ou sinal da crença, expressa uma fé. É uma representação visual do sagrado. Para ser tornar um símbolo religioso, fazse necessário que haja uma motivação a partir de uma crença religiosa. Isso significa, por exemplo, que uma vela acesa em uma casa representa apenas um objeto utilizado para clarear o ambiente, mas se essa mesma vela estiver acesa em um contexto de celebração, culto ou ritual religioso, mesmo que seja na casa, rua ou no templo, ela passa a ter outro significado, visto que a motivação que conduziu a vela àquele status, é uma motivação religiosa, pertencente à crença ou à fé. Portanto, o usuário do símbolo deve ter a intenção de usá-lo como símbolo religioso. Desta forma, o símbolo perde sua interpretação natural, direta, passando a significar outra coisa. (HILL; WHISTLER, 2013). Neste caso, "o símbolo se afirma no sentido transcendente, descartando assim, o sentido literal e comum do material utilizado". (PORTELA, 2013, p. 381). 
Assim, o símbolo pode ter caráter religioso simplesmente porque a comunidade religiosa à qual está ligado assim o reconhece. Ela lhe confere esse caráter e o aceita como elemento que tem sentido e significado com relação à experiência religiosa daquele grupo. Além disso, o símbolo passa a ser objeto de veneração, adoração, proteção, adquirindo, muitas vezes, poderes mágicos e sobrenaturais. Existe no símbolo uma verdade transcendental. "São abstrações de experiências fixadas em formas perceptíveis; [...] representam fontes extrínsecas de informações". (GEERTZ, 2008, p.68).

Os símbolos têm valor porque conferem significados que vão além do seu valor natural. São sinais visíveis de uma teia de significação invisível. Adquirem um valor religioso, pois estão ligados a significados que dão sentido à vida, como a felicidade, a morte e o próprio sentido da existência (ALVES, 2003). Desta forma, os objetos visíveis adquirem uma dimensão nova, passam a ser sinais de realidades invisíveis. "O poder simbólico é um poder de construção da realidade que tende a estabelecer uma ordem gnosiológica: o sentido imediato do mundo (e em particular do mundo social) " (BOURDIEU, 1989, p.9).

Qualquer objeto que faça parte do espaço de celebração de um grupo religioso não se torna automaticamente um símbolo religioso. Porém, todo o espaço religioso pode ser considerado espaço sagrado. $\bigcirc$ fato de alguma coisa pertencer àquele espaço, contudo, não significa que seja, automaticamente, um objeto religioso ou sagrado. $\bigcirc$ objeto religioso pode ser algo utilizado no dia a dia, como, por exemplo, a água, o pão, a vela, alguns alimentos etc. No entanto, no momento em que ele se reveste de um caráter sagrado ou é utilizado em um ritual, passa a ser um símbolo religioso.

○ão utilizado na eucaristia ou ceia é o mesmo utilizado como alimento diário. Porém, a partir do instante em que esse pão está dentro de um contexto de celebração e o sacerdote profere palavras ritualísticas, passa a ter outro caráter, passa a ser visto como sagrado. $\bigcirc$ mesmo fenômeno acontece com rituais de outras tradições, ou seja, elementos comuns passam a ter uma aura sagrada no instante em que são oferecidos à divindade. Assim, qualquer ação de desrespeito ao símbolo será vista pelos fiéis como um sacrilégio visto que aquilo já não é um mero objeto. Ele adquiriu novo significado.

O símbolo religioso está relacionado a uma hierofania, ou seja, à manifestação do sagrado, que passa, de alguma forma, a fazer parte daquele símbolo impregnando-o com seu conteúdo hierático. Todavia, a hierofania não acontece fora da história. Nesse sentido, 
todo símbolo religioso está ligado a um fato preciso, o qual recebe uma interpretação dentro de um momento narrado. "O fenômeno religioso é sempre um fenômeno histórico e, se é histórico, é condicionado. Não há fenômeno religioso em estado puro [...] os fenômenos religiosos são cunhados pelo momento histórico que os viu nascer" [GUIMARÃES, 2000, p. 457]. Nesse sentido, os símbolos representam também uma herança cultural. Eles estabelecem um vínculo entre as imagens que reproduzem e o que representam de fato.

É possível que as pessoas enxerguem com naturalidade, e de forma positiva, a presença de símbolos religiosos no espaço público. Essa concentração de símbolos pode ser entendida como reconhecimento da diversidade religiosa; no entanto, é possível também que a multiplicação da presença desses símbolos esteja relacionada à disputa por espaço. Em algumas cidades onde o poder público construiu algum monumento, seja este alusivo à Bíblia, à imagem de Cristo, à Cruz, à lemanjá, a Oxum, etc., costuma haver reivindicação de outros grupos para a obtenção do mesmo direito de expor suas imagens sagradas, tornando-se, desta forma, disputa pelo mesmo território.

Um exemplo disso é a proposta da vereadora da cidade de Salvador, Cátia Rodrigues, que reivindica a construção, no Dique do Tororó, de um monumento à Bíblia no mesmo espaço e tamanho das imagens dos Orixás que compõem a paisagem do lago Em outras cidades também não é difícil encontrar, muito próximas umas das outras, imagens de lemanjá e um monumento à Bíblia, ou uma gruta na qual há uma imagem de Nossa Senhora.

A pergunta que deve ser feita é a seguinte: por que alguém propõe a construção de um símbolo religioso no mesmo espaço onde já existe outro? Colocar uma Bíblia entre os Orixás, para os protestantes, representa a centralidade da divindade cristã. Simbolicamente, os proponentes podem estar querendo mostrar que sua religiosidade assume um papel central uma vez que o monumento à Bíblia seria colocado em espaço central ou entre os Orixás. Ao mesmo tempo, também podem querer indicar que os Orixás assumem uma posição subserviente. A exaltação da divindade cristã frente a outras

\footnotetext{
${ }^{4}$ Informações mais detalhadas podem ser encontradas em: AGUIAR, Rodrigo. Vereadora quer Bíblia entre orixás do Dique. A Tarde.com. Política. 09 de setembro de 2015. Disponível em: <http:/ / atarde.uol.com.br / / politica/ noticias/1709818-vereadora-propoe-instalacao-de-biblia-no-dique-dotororo>. Acesso em: 23 set. 2015.
} 
é muito destacada nos escritos do Antigo Testamento. Em geral, quando um povo era subjugado, sua divindade praticamente deixava de existir.

Essa concorrência por espaço público demonstra também que a disputa não se dá apenas no nível das repartições públicas, ou seja, ambientes fechados. Atualmente, tem surgido um novo fenômeno: a competição pelo mesmo espaço público aberto, ou seja, praças, ruas, calçadas, parques, rios, praias etc., e esta contenda tem ocorrido devido ao fato de diferentes tradições religiosas reivindicarem o mesmo espaço público aberto.

Um exemplo similar ao anterior relata uma circunstância ocorrida na cidade de Maceió a qual não se refere à construção de nenhum símbolo religioso, mas da disputa pela utilização do mesmo espaço para realização de celebração religiosa. Igualmente à questão anterior, indagamos: por que um grupo religioso propõe realizar uma celebração no mesmo local e horário de outra tradição religiosa? Segundo a informação, no dia 8 de dezembro, os grupos de tradição de matriz africana costumam celebrar festas em homenagem a lemanjá na praia de Pajuçara. No entanto, alguns grupos evangélicos reivindicaram o mesmo espaço para realizar suas celebrações em comemoração ao dia da Bíblia. Vejam que, de forma coincidente ou não, novamente estão em disputa os "Orixás versus Bíblia". Portanto, uma nova modalidade de disputa está se configurando: a demanda pelo espaço público aberto.

A construção desses monumentos indica que nenhum grupo religioso quer ficar em desvantagem em relação ao outro. Eles não querem aparecer como grupo menos importante. Aqui, é possível constatar ainda um resquício que lembra as lutas das divindades. No mundo antigo e judaico-cristão, as divindades costumavam ser apresentadas como mais poderosas do que as dos seus vizinhos. $\bigcirc$ domínio de um povo sobre o outro era também o domínio de uma divindade sobre a outra. Esse pensamento ainda não foi totalmente superado nos dias atuais.

Algumas tradições religiosas ainda trabalham com a ideia de "batalha espiritual". Segundo essa visão, existem algumas tradições religiosas que precisam ser combatidas, porque suas divindades e suas práticas representam o mal. Portanto, de acordo com tal perspectiva, essas divindades, bem como práticas religiosas a elas relacionadas, têm o poder

5 Grupos religiosos disputam orla da Pajuçara para festividades no dia 8 . Informação disponível em: <http:/ / gl.globo.com/al / alagoas/ noticia/ 2015/11 / grupos-religiosos-disputam-orla-da-pajucara-parafestividades-no-dia-8.html>. Acesso em: jan. 2016. 
de influenciar a vida das pessoas gerando comportamentos indesejáveis como miséria, sofrimento, doenças, pobreza, desajustamento familiar etc., afastando cada vez mais as pessoas do que se entende ser a verdadeira divindade. A ideia da batalha espiritual pretende expurgar a sociedade de tudo aquilo que se julga ser de influência maligna. Assim sendo, os apologistas dessa perspectiva se lançam a campo para tentar converter e destruir aquilo que é nomeado como "influência do mal".

Esse tipo de visão dificulta o diálogo, a busca pelo respeito e o combate à

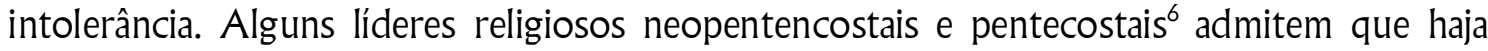
intolerância, no entanto, ressalvam que esta não é causada pelos evangélicos, ou seja, não pode ser creditada aos evangélicos, visto que são ações isoladas, pois são pessoas que agem por conta própria. No entanto, esses líderes esquecem que o tipo de discurso realizado pelas tradições religiosas pode favorecer ou incentivar a intolerância. É importante lembrar, também, que embora alguns líderes neopentecostais e pentecostais concordem que exista intolerância por parte de alguns evangélicos, recusam-se a participar de diálogos ou movimentos que lutam contra a intolerância.

Essa não participação têm duas explicações. A primeira está relacionada ao temor que sentem de que suas comunidades possam vê-los conversando, interagindo e participando de encontros com grupos que eles julgam serem incompatíveis com sua denominação religiosa. A segunda diz respeito à manutenção de um discurso de oposição e combate aos grupos cuja conversão é considerada necessária. Esse discurso é o que alimenta, anima e movimenta algumas tradições religiosas. Nesse sentido, seus líderes não querem abrir mão dessa perspectiva. Eleger uma tradição religiosa como inimiga é a melhor forma de motivar os fiéis a realizarem o proselitismo e contribuírem para o crescimento do seu grupo.

Vejam que uma das preocupações da vereadora da cidade de Salvador era de que o monumento à Bíblia fosse das mesmas dimensões das outras imagens. Isso significa que os símbolos precisam ser grandiosos para que possam ser percebidos. No caso de Porto Alegre, todas as imagens ou monumentos seguem esse princípio. Os símbolos não foram

\footnotetext{
6 São duas linhas do protestantismo. Segundo Ricardo Mariano, LOs Neopentecostais e a Teologia da prosperidade, in: Novos Estudos CEBRAP, n. 44, março, 1996), os pentecostais surgem no início do século XX e suas ênfases doutrinárias consistem na valorização do Batismo com o Espírito Santo, dom de línguas, ascetismo radical de rejeição ao mundo. Os Neopentecostais surgem a partir do final da década de 1970 e início de 1980 e se caracterizam pela doutrina da prosperidade, guerra ou batalha espiritual e por não adotar os estereotipados usos e costumes de santidade.
} 
colocados para serem discretos. Eles demandam atenção dos frequentadores. Não têm a pretensão de serem imperceptíveis. Seus promotores querem que o símbolo seja uma referência, que marque uma posição.

A simbologia religiosa nem sempre é marcada apenas pela disputa de espaço para imagens ou monumentos. De vez em quando, surgem propostas de vereadores pretendendo colocar nos pórticos das cidades dizeres declarando que aquela cidade "é do Senhor Jesus". Foi o que aconteceu em Sorocaba (São Paulo), porém a Justiça os mandou retirar. De acordo com a informação, "a prefeitura terá de remover o totem com a inscrição 'Sorocaba é do Senhor Jesus' [...] e evitar que outros monumentos com a mesma finalidade vinculados a quaisquer denominações religiosas sejam instalados em espaços públicos da cidade" (ROSA, 2014). Nesse caso, houve uma vitória da defesa da laicidade. Não se trata aqui de ser contra a uma inscrição ou mensagem cristã, poderia ser qualquer expressão religiosa de qualquer outro grupo.

\section{Laicidade e símbolo religioso}

Ao olharmos para a sociedade brasileira notamos facilmente que ela é marcada pela presença de tradições religiosas. Isso pode ser percebido pela grande quantidade de templos existentes, pelos inúmeros programas religiosos presentes nos meios de comunicação, pela presença de adeptos que utilizam o espaço público para divulgar suas experiências religiosas e também pelos conflitos que grupos religiosos têm promovido na sociedade. Quando falamos de conflito, estamos nos referindo tanto a pequenos desencontros quanto a grandes atos de intolerância.

A religião na sociedade brasileira remonta ao período da colonização. Há quem diga que a religião faz parte do patrimônio histórico brasileiro. E aqui vale salientar que estamos nos referindo à religião e não ao cristianismo. Embora a tradição cristã seja maioria em nossa sociedade, pensamos que não seja totalmente correto afirmar que a nossa tradição cultural seja cristã. Por esse motivo, cremos que seja mais correto afirmar que a sociedade brasileira possui uma tradição cultural religiosa. A religião está presente na vida do povo. Muitas festas e datas, calendários e feriados são marcados pela expressão religiosa. 
No dia a dia, frequentemente, as pessoas costumam discutir os fatos divulgados pelos meios de comunicação a partir de parâmetros da religião. Uma situação polêmica ou ética nunca é abordada apenas pelo prisma político, sociológico, filosófico ou econômico. A análise é também religiosa. Pensando a partir desse viés, a religião tem potencial para induzir a uma prática, a estabelecer um tipo de comportamento ou visão de mundo.

De fato, o campo religioso brasileiro é marcado por uma hegemonia cristã, mas também apresenta diversidade religiosa. No último censo do IBGE de 2010, o quadro religioso brasileiro se apresentou da seguinte forma: $64,6 \%$ se declararam católicos, $22,2 \%$ afirmaram ser evangélicos, $2 \%$ se dizem espíritas, $0,3 \%$ se declararam umbandistas ou candomblecistas, 2,7\% pertencem a outros grupos religiosos e $8 \%$ se disseram "sem religião".

Definitivamente, a religião tem muita importância na sociedade brasileira, não somente pelos números, mas porque, de fato, podemos apontar sua atuação no dia a dia da vida das pessoas, bem como sua presença nas instâncias políticas da sociedade. A secularização está longe de ser uma realidade no Brasil. Em geral, entende-se a secularização como um processo no qual a religião perde importância ou espaço na sociedade. Ela deixa de ser o parâmetro para a discussão e decisão a respeito dos direitos civis bem como dos valores sociais, éticos e morais. Nesse aspecto, a religião perde controle sobre a vida das pessoas e da sociedade. Peter Berger afirma que "secularização é o processo pelo qual setores da sociedade e da cultura são subtraídos à dominação das instituições e símbolos religiosos" (1985, p. 119).

Às vezes, laicidade e secularização são utilizados como sinônimos, talvez isso se deva à origem dessas palavras. De acordo com Bovero, "laikós tem origem em uma palavra grega, que significa pessoa simples que pertence ao povo (laós). Indivíduo comum, sem distinções, vulgar, pessoa que não faz parte do clero" (2013, p. 3).

Primeiramente, deve-se levar em consideração que, quando falamos de laicidade, estamos nos referindo à separação entre religião e Estado. Essa separação implica dizer que - Estado não é confessional. Não ser confessional significa não optar por uma religião específica. E não optar significa também não impor essa crença a todos os cidadãos. A segunda consideração é a de que o Estado não pode privilegiar nenhum grupo religioso, visto que são interesses do Estado e dinheiro público que estão em jogo. 
A terceira coisa que se deve levar em consideração é de que o Estado e suas decisões não estão subordinadas aos interesses da religião. Por uma questão muito simples: as verdades da religião, em sua maioria, estão ancoradas na revelação divina e servem como regra de fé para quem fez a escolha para seguir determinado grupo. Portanto, é uma escolha pessoal, no âmbito da vida privada. Ao contrário da religião, o Estado não exige como condição de cidadania e desenvolvimento dos compromissos éticos e civis que a pessoa seja ligada a algum grupo religioso. Essas são algumas condições mínimas para o início de conversa sobre o assunto.

A cooperação entre Estado e religião pode ser realizada, segundo Sarmento, se for levada em consideração a seguinte regra:

Certas medidas que impliquem em algum tipo de suporte estatal à religião podem ser consideradas constitucionalmente legítimas, se forem justificáveis a partir de razões não-religiosas, relacionadas à proteção de outros bens jurídicos também acolhidos pela Constituição, cujo peso, no caso concreto, sobrepuje a tutela constitucional da laicidade (SARMENTO, 2007 apud FILÓ; HIJAZ, 2014, p. 170).

Na ordem jurídica brasileira, não há impedimento para que instituições religiosas recebam subvenção ou benefício fiscal do Estado, quando da prestação de algum serviço socialmente relevante, "desde que idêntica vantagem seja concedida, nas mesmas hipóteses e em igualdade de condições, a outras instituições seculares, ou afiliadas a confissões diversas" (MINISTÉRIO, 2014b, 22).

A Suprema Corte dos Estados Unidos ao se pronunciar a respeito de um caso no qual questionava o uso do dinheiro público para financiar uma atividade religiosa, oferecenos uma série de regras que, talvez, sejam relevantes para quem deseja pensar a respeito da laicidade.

Nenhum estado nem o governo federal podem estabelecer uma igreja. Nenhum pode promulgar leis que auxiliem uma religião, auxiliem todas as religiões, ou prefiram uma religião sobre outra. Nenhum estado pode forçar ou influenciar uma pessoa a ir ou continuar distante de uma igreja contra sua vontade, ou forçá-la a professar uma crença ou descrença em qualquer religião. Nenhuma pessoa pode ser punida por sustentar ou professar crenças ou descrenças religiosas, ou por comparecer ou não comparecer a uma igreja. Nenhum imposto em nenhuma quantia, grande ou pequena, pode ser instituído para apoiar qualquer atividade ou instituição religiosa, independentemente de como sejam chamadas ou qualquer que seja a forma que elas possam adotar para ensinar ou praticar religião. Nenhum estado nem o governo federal pode, aberta ou secretamente, participar nos negócios de quaisquer organizações ou grupos religiosos e vice-versa (CINTRA, 2014, p.45). 
Estado deve garantir o mesmo tratamento a todas as confissões religiosas, garantindo a liberdade de expressão também aos que não creem. "O Estado é, como se costuma dizer (e em princípio), neutro em relação aos grupos, tolerando a todos, e autônomo em seus objetivos" (WALZER, 1999, p.43). Segundo Bovero,

Laicidade é definida em primeiro lugar pela independência de juízos com respeito as afirmações ou crenças apoiadas por uma autoridade. A laicidade é ausência de dogmas, do que é imposto, aceito e crido como irrefutável. O princípio teórico do pensamento laico é, portanto, antidogmático. Laico é aquele que promove um espírito crítico frente a um espírito dogmático, e por isso reivindica o direito de heterodoxia em qualquer campo, para si e para os que pensam diferente dele. (2013, p.16).

Beckford e Demerath definem laicidade como "regime social no qual as instituições políticas não estão mais legitimadas pelas instituições sagradas ou religiosas, mas pela soberania ou vontade popular" (2007, p. 724). Isto significa que setores da sociedade e da cultura não estão mais sob o domínio das instituições religiosas. De acordo com essa definição, não há intenção em eliminar a religião da sociedade, mas em livrar a sociedade do domínio da religião.

As posturas relacionadas à discussão da laicidade vão desde os que entendem que numa sociedade laica a religião perde importância e se limita apenas aos espaços privados àqueles que defendem que a constituição de uma sociedade laica não elimina definitivamente a participação da religião na sociedade e sua relação com o Estado. Nesse sentido, pensando de acordo com o primeiro grupo, o espaço público deveria estar desprovido de qualquer presença religiosa. Essa mesma linha entende também que o Estado não deve se comportar como promotor de nenhum grupo religioso e nem mesmo promover a diversidade religiosa. Portanto, segundo esse pensamento, não é papel do Estado promover diversidade religiosa. Blancarte vai nessa direção quando afirma que "o Estado é laico quando prescinde da religião, quando já não requer mais a religião como elemento de integração social ou como cimento para a unidade nacional (...). Por isso, o Estado laico surge realmente quando a origem dessa soberania já não é sagrada e sim popular". (BLANCARTE apud ORO, 2011, p. 222).

Quem pensa dessa forma entende também que o grupo religioso se constitui a partir de uma sociedade que se caracteriza por interesse e escolha individuais. É uma 
escolha de caráter privado, particular ao contrário do Estado que legisla para a população como um todo. $O$ direito à cidadania e aos benefícios que dela advêm não estão subordinados ao pertencimento a um grupo religioso. Os direitos de qualquer cidadão independem de sua ligação com um grupo religioso. As verdades da religião, em sua maioria, estão ancoradas na revelação divina e servem como regra de fé para quem fez a escolha para seguir determinado grupo. Portanto, é uma escolha pessoal, no âmbito da vida privada. Ao contrário da religião, o Estado não exige como condição de cidadania e desenvolvimento dos compromissos éticos e civis que a pessoa esteja ligada a algum grupo religioso.

\section{Resultados: Presença de símbolos religiosos em espaços púbicos}

O que os dados colhidos na pesquisa nos informaram? Salientamos que os resultados aqui apresentados foram colocados de forma resumida, visto que o formato deste trabalho não permite expor a análise de forma exaustiva.

Percebe-se que há poucos símbolos religiosos em espaços públicos abertos na cidade de Porto Alegre. No entanto, os que existem são símbolos grandiosos e ostensivos. Ou seja, não se trata de uma pequena placa ou um monumento escondido sem nenhuma expressão, pelo contrário, os símbolos são muito visíveis em sua estrutura, isto é, são imagens grandes e posicionadas em locais de muita circulação.

A maioria dos entrevistados (90\%) aceita a presença do símbolo naquele espaço. Dos que se colocaram contra, apenas um evocou a laicidade do Estado como motivo para a não presença do símbolo. Este participante não enxerga problema na presença do símbolo no espaço público aberto, somente nos espaços fechados. Para ele, a presença do símbolo no espaço público pode significar uma oportunidade de troca de cultura. De acordo com essa visão, a diversidade cultural também se expressa por meio do símbolo religioso. $\bigcirc$ participante conseguiu identificar, através do símbolo, a expressão cultural do grupo. Uma visão com esse enfoque demonstra que a cultura brasileira não é somente marcada pelo homem branco europeu, mas também pelos povos indígenas, negros, orientais etc.

Esse entendimento vai ao encontro da representatividade dos símbolos escolhidos. A Bíblia, além de regra de fé e prática do cristianismo, é também expressão de uma 
religiosidade europeia, branca e patriarcal. $\bigcirc$ Candelabro representa uma religiosidade que está intimamente ligada ao judaísmo ao ponto de não haver separação entre ser judeu e ter o judaísmo como religião. Nesse caso, religião, cultura e etnia se misturam. Segundo Gorestein, "a identidade judaica pode ser considerada como uma identidade étnica condicionada por dois fatores: o religioso e o nacional (enquanto povo e não um Estado)" (2005, p. 57).

Podemos considerar a mesma ideia em relação à religiosidade de matriz africana. A religiosidade, nesse caso, também está imbricada com a cultura, ou seja, a dança, o alimento, a música, a estética, a forma de pensar e o modo de ser caminham de mãos dadas com a religião e a cultura.

Talvez seja por esse motivo que, no Brasil, ainda haja resistência ao reconhecimento e promoção da diversidade tanto religiosa quanto cultural, principalmente, quando se refere à cultura dos povos de origem africana ou orientais. Como a cultura brasileira é marcada hegemonicamente pela expressão cultural branca europeia, os grupos religiosos cristãos e parte da elite relutam e resistem à cultura de matriz afro.

Da mesma forma, a cultura oriental ainda é vista, pelo menos no meio cristão protestante conservador, como seita, como algo esquisito, exótico, supersticioso, atrasado e de adoração a falsas divindades. Ademais, a visão que se tem desses grupos é a de que vivem em um mundo atrasado e opressor no qual a liberdade não tem vez. Principalmente quando se refere ao mundo muçulmano.

O restante dos participantes da entrevista justificou a não aceitação da presença do símbolo pelo fato de que a religiosidade é algo pessoal, portanto, cada um deve cultuar seus símbolos em seus locais de culto específicos, em sua privacidade. Para um entrevistado, a religião não precisa se expressar publicamente. No Brasil, várias tradições religiosas utilizam o espaço público para realizar manifestações religiosas, como celebrações, cultos, passeatas, protestos e divulgação de sua fé. Algumas chegam a causar constrangimento ao abordar pessoas nas ruas ou em suas residências. Aqui no Brasil, essas abordagens e divulgação da fé em locais públicos são vistas com normalidade. No entanto, em alguns países europeus, há discussão para limitar ou até mesmo proibir esse tipo de expressão ou presença de símbolos religiosos.

Países como a França, Bélgica e Itália criaram leis proibindo o uso da burca e niqab em lugares públicos. Em relação à França, esta é conhecida por sua posição no que se 
refere à presença de símbolos religiosos em espaços públicos principalmente nas escolas. As escolas francesas proibiram o uso de símbolos religiosos, como kippah, lenço islâmico e cruz cristã. "Atualmente na França, laicismo é uma arma utilizada principalmente contra militantes islâmicos" (BIZEUL, 2013, p. 38).

Outra entrevistada alegou que o símbolo maior é Jesus Cristo, por esse motivo não deveria haver outros símbolos. Nota-se nessa última resposta a ideia que desenvolvemos anteriormente, ou seja, o fiel enxerga sua divindade ou seu símbolo como o mais importante. A divindade maior ou mais importante deve prevalecer em relação às divindades consideradas menores, inferiores ou menos importantes. Aqui ainda temos um resquício do pensamento religioso que não admite a representação física da divindade. No protestantismo, assim como no islamismo, não se admite a representação de divindades nem de santos. Para o primeiro, o único símbolo que pode ser representado é a Bíblia. $\bigcirc$ fato de considerar que Jesus é o símbolo maior pode contribuir para enfatizar que as outras divindades são coadjuvantes, que não deveriam existir ou que são invenções humanas.

Foi possível constatar, na presente pesquisa, que a religião da pessoa não influenciou na rejeição ao símbolo. Isto é, esperava-se que um protestante ou mesmo um católico se posicionasse contra uma imagem de Oxum ou, ainda, quem não fosse budista rejeitasse o Buda. No entanto, isso não ocorreu. Em apenas dois casos, os entrevistados utilizaram sua tradição religiosa para não aceitar a presença de outro símbolo religioso. Curiosamente uma dessas entrevistadas rejeitou o símbolo do Candelabro - símbolo da tradição judaica que é muito próximo e tem bastante relação com a tradição cristã. É possível que ela tenha o confundido ou não tenha conhecimento que se tratava de um símbolo judaico.

A religiosidade brasileira já foi vista, por muitos pesquisadores, como resultado do sincretismo; no entanto, este sincretismo estava restrito ao mundo católico e às tradições de matriz africana. Um novo fenômeno, contudo, tem surgido. As igrejas, principalmente de tradição neopentecostal, têm introduzido ou incorporado símbolos do judaísmo em suas celebrações e em seus altares.

No que diz respeito às igrejas neopentecostais, é cada vez mais comum a apropriação de símbolos, rituais e trechos da liturgia judaica. Entre eles têm destaque a estrela de David (na bandeira do Estado de Israel ou simplesmente 
como um ornamento dentro das igrejas), a menorá (candelabro de sete braços), o shofar (chifre de carneiro cujo som tem lugar destacado nas comemorações do Ano Novo Judaico e no Dia da Expiação), o talit (acessório em forma de xale usado pelos judeus ortodoxos), réplicas da Arca da Aliança e passagens escritas em hebraico, tanto nos livros litúrgicos como nas paredes dos prédios dessas igrejas (TOPEL, 2011, p. 35).

Como salientamos, apenas duas entrevistadas utilizaram o argumento de sua tradição religiosa para rejeitar a presença do símbolo de outro grupo. Em geral, os argumentos que os entrevistados utilizaram para justificar a presença do símbolo dizem respeito a questões relacionadas ao reconhecimento da diversidade e ao direito que todas as tradições têm de manifestar a sua fé.

Ficou evidente também a ideia de respeito pela outra tradição religiosa. $O$ símbolo demonstra a importância da fé, da espiritualidade, da crença e da devoção. Para esses, os símbolos são expressões visíveis dessas crenças. Nesse aspecto, a presença dos vários símbolos indica uma tolerância e um sentido de democracia no uso do espaço público visto que outros também são contemplados com seus símbolos. Para os entrevistados, se houvesse o domínio de apenas um símbolo religioso, isso poderia ser visto de forma negativa. Porém, como também há presença de símbolos de outras tradições, isso demonstra "uma certa convivência pacífica", civilizada e democrática considerando que o poder público não está favorecendo apenas a uma tradição. Essa ideia vai ao encontro do que diz a Declaração Universal da Laicidade, em seu artigo 14: o Estado deve garantir o direito de todos se expressarem; este é um princípio da laicidade.

Contrariamente, o que se teme em determinadas sociedades, a laicidade não significa abolir a religião, mas a liberdade de decisão em matéria de religião. Isso também implica, nos dias de hoje, onde necessário, desligar o religioso daquilo que se encontra assentado na sociedade e de todas as imposições políticas (BARBÉROT, MILOT, BLANCARTE, 2005).

Nesse sentido, a diversidade religiosa pode ser entendida como reconhecimento e garantia do convívio respeitoso entre as múltiplas e variadas experiências ou tradições religiosas que convivem no mesmo espaço social. Discutir a laicidade é discutir também a necessidade de reconhecimento da diversidade, pluralidade e igualdade religiosa. No entanto, mesmo admitindo que essa seja uma visão positiva em relação ao reconhecimento e à promoção da diversidade, devemos também destacar que em algumas cidades a construção de símbolos religiosos têm se tornado um problema, visto que a suas 
prefeituras têm patrocinado a construção de imagens ou pórticos com dizeres religiosos. Essa atitude gera alguns problemas. Primeiro: há utilização de dinheiro público para patrocinar um símbolo ou tradição religiosa específica. Segundo: há utilização do espaço público. Em outras ocasiões não há envolvimento de dinheiro público, mas há utilização do espaço. Portanto, a grande questão é: como conciliar a utilização do espaço público ao mesmo tempo em que se promove a diversidade religiosa? Ou ainda: qual é o limite da relação entre o poder público e a religião?

\section{Vl. Conclusão}

A maioria dos entrevistados enxergou com naturalidade a presença do símbolo religioso no espaço público, quer dizer, não conseguem perceber isso como um problema. Existe uma naturalização dessa realidade.

O conceito de laicidade que transparece nas entrevistas converge para a ideia de um gestor público como o garantidor da democracia no que se refere ao direito de todas as religiões se manifestarem. Esse direito não exclui o espaço público, ou seja, a gestão pública contempla a laicidade quando reconhece todas as tradições religiosas como válidas e, democraticamente, cede o espaço público para que elas possam se manifestar. Nesse sentido, laicidade é vista como uma forma de reconhecimento da diversidade e uma maneira de promover o respeito e igualdade entre os grupos religiosos. Assim sendo, o espaço público pode ser utilizado e destinado a esse fim desde que se garanta o respeito pela diversidade e igualdade nas relações entre os grupos religiosos.

Portanto, esse tipo de compreensão compromete o próprio conceito de laicidade e o processo de implementação de um Estado laico, visto que a expressão da experiência ou tradição religiosa é resultado de uma prática privada; porém, as pessoas entrevistadas não veem problema na presença dos símbolos nos espaços públicos nem na relação que o gestor público estabelece no sentido de beneficiar os grupos religiosos.

Diferentemente de alguns estados europeus que se empenham em promover a secularização e impor barreiras para o desenvolvimento das religiões, defendemos que o Estado brasileiro deva garantir o direito à diversidade religiosa, à liberdade e à igualdade entre os vários grupos religiosos, bem como promover a laicidade, o respeito e o combate à intolerância. Agindo desta forma, entendemos que seja possível a convivência entre um 
Estado que promove a diversidade religiosa, mas que, ao mesmo tempo, garanta a laicidade.

Nesse sentido, os símbolos religiosos em espaços públicos podem significar empecilho para a convivência pacífica quando representam exclusividade, privilégio, disputa de território e poder, ou quando o grupo religioso lança mão do poder público para garantir privilégios, utilizando o bem público em benefício próprio. No nosso país, a hegemonia religiosa representa também poder político. Se essa relação não ficar bem transparente, pode representar ameaça à laicidade.

\section{Referências Bibliográficas}

ALVES, Rubem. O que é religião. São Paulo: Loyola, 1999.

BAUBÉROT, Jean, MILOT, Micheline, BLANCARTE, Roberto. Declaração Universal da Laicidade no século XXI. 9 de dezembro de 2005. Disponível em: <http:/ / www.bulevoador.com.br/2009/ 09/ declaracao-universal-da-laicidade-no-seculoxxi / > Acesso em: jan. 2016.

BECKFORD, James A.; DEMERATH, N.J. The sage handbook of the Sociology of Relligion. London: Sage Publication, 2007.

BERGER, Peter. O Dossel Sagrado. Elementos para uma teoria sociológica da religião. São Paulo: Paulus, 1985.

BIZEUL, Yves. Secularism in Europe. Bruxelles: European Liberal Forum asbl, 2013.

BOURDIEU, Pierre. O poder simbólico. Lisboa: Difel / Rio de Janeiro: Editora Bertrand, 1989.

BOVERO, Michelangelo. El concepto de laicidad. Mexico: Universidad Nacional Autónoma de México, Instituto de Investigaciones Juríricas, 2013.

CINTRA, Fernando Vogel. A defesa do Estado Laico pelo Ministério Público: Uma perspectiva comparada a partir do direito estadunidense. In: MINISTÉRIO PÚBLICO EM DEFESA DO ESTADO LAICO. Conselho Nacional do Ministério Público. Brasília: CNMP, 2014. Vol. 1. 
FILÓ, Maurício da Cunha Savino; HIJAZ, Tailine Fátima. O princípio da laicidade do Estado e a manutenção de símbolos religiosos em espaços públicos: análise da decisão do Conselho da Magistratura do Tribunal de Justiça do Rio Grande do Sul. In: MINISTÉRIO PÚBLICO EM DEFESA DO ESTADO LAICO. Conselho Nacional do Ministério Público. Brasília: CNMP, 2014b. Vol. 1.

GEERTZ, Clifford. A interpretação das culturas. Rio de Janeiro: LTC, 2008.

GIUMBELLI, Emerson. Símbolos religiosos em controvérsias. São Paulo: Terceiro Nome, 2014.

GONDIM, Ricardo. Deus me livre de um Brasil evangélico. Disponível em: <http:/ / www.ricardogondim.com.br/ meditacoes/ deus-nos-livre-de-um-brasil-evangelico / > Acesso em: set. 2015.

GORESTEIN, Lina. Mulheres da nação cristã-nova: as marranas do Rio de Janeiro (século XVIII). In: LEWIN, Helena. Identidade e cidadania. Como se expressa o judaísmo brasileiro. Rio de Janeiro: Centro Edelstein de Pesquisas Sociais, 2009.

GUIMARÃES, André Eduardo. O sagrado e a História. Fenômeno religioso e valorização da história à luz do anti-historicismo de Mircea Eliade. Porto Alegre: Edipucrs, 2000.

HILL, Daniel J.; WHISTLER, Daniel. The right to wear the religious symbols. New York: Palgrave Macmillan, 2013.

MARIANO, Ricardo. Os Neopentecostais e a Teologia da prosperidade. In: Novos Estudos CEBRAP n. 44, março, 1996.

PORTELA, Bruno de O. S. Conceito de símbolo em Tillich e Jung. In: Revista Lusófona de Ciência das Religiões. Ano X, 2013. n. 18 e 19.

ROSA, José Antônio. Justiça manda retirar o totem religioso da entrada da cidade. Jornal Cruzeiro do Sul. Disponível em: <http:/ / www.jornalcruzeiro.com.br/ materia / 538478/ justica-manda-retirar-o-totemreligioso-da-entrada-da-cidade> Acesso em: set. 2015.

TOPEL. Marta Francisca. Revista Brasileira de História das Religiões. ANPUH, Ano IV, n. 10, Maio 2011.

WALZER, Michael. Da tolerância. São Paulo: Martins Fontes, 1999. 